\title{
THE IMPACT OF SOCIAL MEDIA USAGE TO ACADEMIC PERFORMANCE
}

\author{
Suita Allemina Gloria ${ }^{1}$, Surya Akbar ${ }^{1 *}$
}

${ }^{1}$ Fakultas Kedokteran Universitas Islam Sumatera Utara, Medan - INDONESIA

\begin{abstract}
Background: Social media is basically a tool for someone to interact with other people with use of internet. In futher, social media is not only used as a tool for interact with others, but it can be used on learning process. This study aims to analyse correlation betwen duration of using a social media with academic performance.

Method: This study used a cross sectional design. Respondents on this study are 126 undergraduates students on fourth years in Faculty of Medicine, Universitas Islam Sumatera Utara. Using of a social media are measured by how long a student use of a social media based on their purpose (learning or entertainment). Results from the measurement will grouping into two different group, that is using of a social media for learning group and for entertainment group. The academic performance was measured by calculating a Grade Point Average (GPA) of each student. The collected data were analyzed by using Spearman Correlation method.

Results: There was a significant correlation betwen duration of using a social media for learning process with academic performance $(r=0,554, p=0,0001)$. Similarly, there are a significant correlation betwen duration of using a social media for entertainment with academic performance $(r=-0,568, p=0,0001)$, but the coefficient correlation have a negative value.

Conclusion: The social media have an impact to academic performance, where the students who used more social media as a learning process have a good GPA and the students who used more social media as a entertainment have a bad GPA. Sugesstions that can be given based on this study are the use of social media can be considered as a tool for helping students enhancing learning process.
\end{abstract}

Keywords: media sosial, learning achievement.

\begin{abstract}
ABSTRAK
Latar belakang: Media sosial pada dasarnya merupakan suatu media (wahana) bagi seseorang untuk dapat berinteraksi secara tidak langsung dengan orang lain melalui jaringan internet. Pada perkembangannya media sosial tidak hanya digunakan sebagai alat untuk berinteraksi dengan orang lain, tetapi juga berperan dalam proses belajar. Tujuan penelitian ini adalah untuk melihat hubungan penggunaan media sosial terhadap prestasi akademik mahasiswa.

Metode: Penelitian ini menggunakan desain potong lintang. Responden dalam penelitian adalah seluruh mahasiswa semester akhir program pendidikan dokter Fakultas Kedokteran UISU yang berjumlah 126 orang. Pengukuran dilakukan pada lama penggunaan masing-masing media sosial berdasarkan tujuan penggunaannya. Hasil pengukuran akan menggelompokkan menjadi dua kelompok, yaitu pengguna media sosial sebagai sarana belajar dan sebagai sarana hiburan. Prestasi akademik mahasiswa diperoleh dari hasil perhitungan IP (Indeks Prestasi) setiap mahasiswa. Data yang diperoleh akan dianalisis dengan menggunakan uji korelasi Spearman.
\end{abstract}

*corresponding author, contact: surya.akbar@fk.uisu.ac.id 
Hasil: Analisis korelasi Spearman diperoleh hubungan yang signifikan antara durasi penggunaan media sosial sebagai sarana belajar dengan prestasi akademik mahasiswa $(r=0,554, p=0,0001)$. Begitu pula pada uji korelasi antara durasi penggunaan media sosial sebagai sarana hiburan terhadap prestasi akademik, dimana kedua variabel tersebut berhubungan secara terbalik $(r=-0,568, p=0,0001)$.

Kesimpulan: Media sosial memiliki dampak terhadap prestasi akademis mahasiswa baik secara positif maupun negatif yang tergantung pada tujuan penggunaan media sosial itu sendiri. Mahasiswa yang menggunakan media sosial sebagai sarana belajar akan memiliki prestasi akademis yang lebih baik dibandingkan mahasiswa yang menggunakan media sosial sebagai sarana hiburan. Saran yang bisa disampaikan pada penelitian ini adalah penggunaan media sosial dapat dipertimbangkan sebagai alat untuk membantu mahasiswa dalam melakukan proses belajar.

Kata kunci: sosial media, prestasi akademik.

\section{PENDAHULUAN}

Keberhasilan seorang mahasiswa dalam satu bidang akademik formal tertentu ditandai dengan prestasi akademik yang dicapai pada akhir semester, dimana prestasi akademis tersebut disampaikan dalam bentuk Indeks Prestasi (IP). ${ }^{1}$ Indeks Prestasi adalah nilai kredit rata-rata yang merupakan satuan nilai akhir yang menggambarkan nilai proses belajar tiap semester atau dapat diartikan juga sebagai besaran atau angka yang menyatakan prestasi keberhasilan dalam proses belajar mahasiswa pada satu semester. Mahasiswa yang memperoleh IP tinggi mengindikasikan bahwa mahasiswa tersebut mampu mengikuti kuliah dengan baik, begitu pula sebaliknya. ${ }^{2}$

Keberhasilan mahasiswa dalam menguasai ilmu pada satu proses belajar tertentu dapat dipengaruhi oleh berbagai faktor. Secara garis besar, faktor-faktor yang mempengaruhi keberhasilan belajar itu dapat dibagi menjadi 2 bagian besar, yaitu faktor internal dan faktor eksternal. ${ }^{3}$ Faktor internal adalah faktor yang terdapat di dalam diri individu itu sendiri, seperti kesehatan jasmani dan rohani, kecerdasan (intelegensia), daya ingat, kemauan dan bakat. Sedangkan yang dimaksud dengan faktor eksternal adalah faktor yang berasal dari luar diri individu, seperti keadaan lingkungan rumah, kampus, masyarakat, dan segala sesuatu yang berhubungan dengan kegiatan belajar.

Salah satu faktor eksternal yang sekarang ini dianggap dapat memberi sumbangan besar dalam keberhasilan belajar seseorang adalah penggunaan media sosial. Media sosial merupakan salah satu media online dimana para penggunanya dapat ikut serta dalam mencari informasi, berkomunikasi, dan menjaring pertemanan dengan segala fasilitas dan aplikasi yang dimilikinya. Kehadiran media sosial telah membawa pengaruh tersendiri terhadap kegiatan yang dilakukan oleh manusia saat ini. ${ }^{4}$ Adapun yang termasuk dalam media sosial menurut Nasrullah adalah: facebook, twitter, instagram, youtube, blogger, path, snapchat dan wiki. ${ }^{5}$ Sedangkan line, whatsapp, bbm (blackberry messenger) dan sejenisnya bukanlah termasuk ke dalam media sosial, namun termasuk dalam instant messenger (pesan instan). ${ }^{6}$ Walaupun sekarang ini pesan instan dapat dikelompokkan dalam media sosial, namun bila melihat bentuk awal dari masing-masing aplikasi tersebut maka dapat dilihat bahwa whatsapp, bbm dan line termasuk dalam kelompok pesan instan.

Penelitian Setyaningrum yang meneliti tentang pengaruh penggunaan media jejaring sosial terhadap prestasi akademik di Fakultas Ilmu Pendidikan Malang menemukan bahwa terdapat hubungan yang signifikan antara penggunaan media sosial dengan prestasi akademik mahasiswa $(\mathrm{r}=0,118)$. ${ }^{7}$ Pada penelitian tersebut, dapat dilihat hubungan yang diperoleh dari nilai koefisien korelasi memiliki nilai yang tergolong sangat lemah dan dengan arah yang positif.

Penelitian yang serupa juga pernah dilakukan oleh Pramudawardani kepada mahasiswa program studi 
pendidikan IPS yang juga memperlihatkan adanya hubungan yang signifikan antara penggunaan jejaring sosial dengan nilai prestasi akademik mahasiswa $(r=-0,248)$. Berdasarkan hasil penelitian tersebut, maka dapat dilihat hubungan diantara kedua variabel tersebut bersifat negatif, dimana bila penggunaan media sosial tinggi pada mahasiswa maka prestasi akademik mahasiswa tersebut akan cederung rendah, begitu pula sebaliknya. ${ }^{8}$

Kedua penelitian diatas memiliki persepsi berbeda dalam meneliti hubungan penggunaan media sosial, dimana pada penelitian Pramuwardani penggunaan media sosial yang dimaksud hanya pada dua jenis media sosial saja, yaitu Facebook dan Twitter, sedangkan media sosial lainnya tidak diukur. Pengukuran penggunaan media sosial tersebut juga tidak mempertimbangkan tujuan dari penggunaan media sosial tersebut, apakah digunakan sebagai sarana belajar atau sebagai sarana hiburan. Pada penelitian Setyanigrum, tidak dilakukan pemisahan antara media sosial dan pesan instan sehingga gambaran hubungan media sosial dengan prestasi akademik belum jelas tergambarkan.

Penelitian ini pada dasarnya adalah kelanjutan dari penelitian-penelitian tersebut, dimana penelitian ini memiliki kelebihan dalam hal pengukuran penggunaan dan jenis media sosial yang digunakan. Pengukuran terhadap penggunaan media sosial pada penelitian ini dilakukan pada setiap jenis media sosial (tidak termasuk pesan instan); lebih spesifik dalam tujuan dari penggunaan masingmasing media sosial (apakah ditujukan untuk saran belajar atau hanya sebagai sarana hiburan); tidak menggabungkan antara media sosial dan pesan instan.

Berdasarkan uraian di atas, peneliti tertarik untuk melakukan penelitian yang tentang hubungan penggunaan media sosial dengan indeks prestasi akademik pada mahasiswa Fakultas Kedokteran UISU. Penilaian hubungan tersebut dilakukan dengan memisahkan penggunaan media sosial sebagai sarana belajar dengan penggunaan media sosial sebagai saran hiburan. Pemisahan tersebut ditujukan agar dampak penggunaan media sosial (sebagai sarana belajar atau sarana hiburan) dapat lebih tergambarkan.

\section{METODE}

Penelitian ini menggunakan desain studi Potong Lintang dan menggunakan uji analisis korelasi Spearman. Uji korelasi Spearman digunakan karena berdasarkan hasil uji normalitas data menggunakan uji Kolmogorov Smirnov didapatkan hasil data yang diperoleh tidak terdistribusi normal.

Lokasi penelitian dilakukan di Fakultas Kedokteran UISU (FK UISU) Medan dengan responden penelitian adalah seluruh mahasiswa semester akhir (semester 7) program pendidikan dokter yang berjumlah 126 orang. Tidak ditemukan adanya penolakan pada mahasiswa, sehingga seluruh mahasiswa bersedia menjadi responden dalam penelitian ini. Pengumpulan data dilakukan dengan menggunakan alat ukur berupa kuesioner yang terdiri dari 9 pertanyaan (3 pertanyaan untuk menilai penggunaan media sosial sebagai sarana belajar, dan 6 untuk menilai penggunaaan media sosial sebagai sarana hiburan). Pertanyaan pada kuesioner disampaikan dalam bentuk pertanyaan terbuka yaitu menanyakan tentang jumlah jam mahasiswa mengakses media sosial dengan tujuan tertentu. Contoh pertanyaan dalam kuesioner tersebut adalah: "Selama 1 minggu ini, berapa jam rata-rata anda mengakses Youtube untuk proses belajar dalam sehari?", "Selama 1 minggu ini, berapa jam rata-rata anda mengakses media sosial Youtube sebagai hiburan dalam sehari?". Jawaban dari masing-masing pertanyaan akan disampaikan dalam bentuk rata-rata jam/hari. Media sosial yang diukur masa pemakaiannya oleh responden dalam sehari diantaranya adalah sebagai berikut: "Sebagai sarana belajar": Youtube, Wikipedia, Blogger; "Sebagai sarana hiburan": Youtube, Facebook, Path, Twitter, Instagram, Snapchat. Pengukuran prestasi akademik mahasiswa dilakukan dengan melihat Indeks Prestasi (IP) pada semester berlangsung di dalam program SIAKAD (Sistem Informasi Akademik) FK UISU.

Sebelum mengumpulkan data dari responden, peneliti terlebih dahulu mengajukan kelayakan etik ke Komisi Etik Penelitian Kesehatan (KEPK) FK UISU. Pengumpulan data oleh peneliti dilakukan langsung oleh peneliti pertama, dimana peneliti mendampingi secara langsung disaat responden mengisi kuesioner. 


\section{HASIL DAN PEMBAHASAN}

Peneliti tidak menemukan adanya responden yang menolak mengikuti penelitian ini, sehingga seluruh responden dalam penelitian ini mengisi kuesioner yang diberikan oleh peneliti. Data yang diperoleh pada dasarnya terdiri atas 2 kelompok, yaitu: ratarata jam penggunaan media sosial sebagai sarana belajar, dan rata-rata jam penggunaan media sosial sebagai sarana hiburan.

Tabel 1. Rata-Rata Penggunaan Media Sosial Berdasarkan Aplikasi Yang Diakses

\begin{tabular}{lc}
\multicolumn{1}{c}{$\begin{array}{c}\text { Penggunaan } \\
\text { Media Sosial }\end{array}$} & $\begin{array}{c}\text { Rata-Rata Penggunaan } \\
\text { Media Sosial (jam/hari) }\end{array}$ \\
\hline Sarana Belajar & \\
- Youtube & 1,74 \\
- Wikipedia & 1,17 \\
- Blogger & 0,68 \\
Sarana Hiburan & \\
- Youtube & 2,63 \\
- Facebook & 0,80 \\
- Path & 0,22 \\
- Twitter & 0,33 \\
- Instagram & 5,97 \\
- Snapchat & 0,28 \\
\hline
\end{tabular}

Tabel di atas memperlihatkan bahwa mahasiswa lebih banyak membuka media sosial untuk hiburan dan aplikasi yang paling lama dibuka adalah instagram. Sedangkan penggunaan media sosial sebagai sarana belajar yang paling lama dibuka adalah aplikasi youtube.

Bila dilakukan pengelompokan pada data di atas berdasarkan kategori < 1,0 jam; 1,0-2,0 jam; 2,1-4,0 jam; dan > 4,0 jam dan pada kelompok penggunaan media sosial sebagai sarana belajar, maka dapat dilihat bahwa kebanyakan mahasiswa menggunakan media sosial hanya selama $<1,0$ jam/hari-nya (tabel 2). Walaupun demikian, masih dijumpai sejumlah kecil mahasiswa yang menggunakan media sosial sebagai sarana belajar selama lebih dari 4 jam dalam sehari.
Tabel 2. Distribusi Frekuensi Lama Penggunaan Media Sosial Untuk Belajar

\begin{tabular}{ccc}
$\begin{array}{c}\text { Lama Penggunaan } \\
\text { Media Sosial }\end{array}$ & Frekuensi & Persentase \\
$<1,0$ jam & 67 & $53,2 \%$ \\
$1,0-2,0$ jam & 48 & $38,1 \%$ \\
$2,1-4,0$ jam & 9 & $7,1 \%$ \\
$>4,0$ jam & 2 & $1,6 \%$ \\
\hline Total & 126 & $100 \%$ \\
\hline
\end{tabular}

Sedangkan untuk lama penggunaan media sosial sebagai hiburan, kebanyakan mahasiswa menggunakan media sosial antara 1,0-2,0 jam hingga 2,1-4,0 jam (tabel 3). Namun, mahasiswa yang membuka aplikasi media sosial dengan tujuan sebagai hiburan sangat sedikit yang menggunakannya lebih dari 4 jam sehari.

Tabel 3. Distribusi Frekuensi Lama Penggunaan Media Sosial Untuk Sarana Hiburan

\begin{tabular}{ccc}
$\begin{array}{c}\text { Lama Penggunaan } \\
\text { Media Sosial }\end{array}$ & Frekuensi & Persentase \\
$<1,0$ jam & 35 & $27,8 \%$ \\
$1,0-2,0$ jam & 49 & $38,9 \%$ \\
$2,1-4,0$ jam & 36 & $28,6 \%$ \\
$>4,0$ jam & 6 & $4,8 \%$ \\
\hline Total & 126 & $100 \%$ \\
\hline
\end{tabular}

Kemampuan mahasiswa dalam belajar dapat digambarkan dari Indeks Prestasi (IP)-nya. Agar memudahkan pembaca dalam melihat gambaran kemampuan mahasiswa, maka IP setiap mahasiswa akan dikelompokkan menjadi dua kelompok, yaitu kelompok $<2,75$ dan kelompok $\geq 2,75$. Indeks Prestasi mahasiswa diambil secara langsung dari data program SIAKAD Program Studi Sarjana Kedokteran FK UISU. 
Tabel 4. Distribusi Frekuensi Indeks Prestasi Mahasiswa Semester 7

\begin{tabular}{ccc} 
Indeks Prestasi & Frekuensi & Persentase \\
$<2,75$ & 9 & $7,1 \%$ \\
$\geq 2,75$ & 117 & $92,9 \%$ \\
\hline Total & 126 & $100 \%$
\end{tabular}

Berdasarkan pengelompokan tersebut, dapat dilihat bahwa kebanyakan responden berada pada kelompok IP di atas 2,75. Hal ini berarti mayoritas responden yang diambil dalam penelitian ini memiliki prestasi akademis yang baik.

Tabel 5. Hubungan Lama Penggunaan Media Sosial Sebagai Sarana Belajar dengan Indeks Prestasi

\begin{tabular}{|c|c|c|c|}
\hline & \multicolumn{3}{|c|}{ Indeks Prestasi (IP) } \\
\hline & $\mathbf{n}$ & $\mathbf{r}$ & $p$ \\
\hline $\begin{array}{l}\text { Lama Penggunaan } \\
\text { Media Sosial }\end{array}$ & 126 & 0,554 & 0,0001 \\
\hline
\end{tabular}

Penilaian hubungan lama penggunana media sosial dengan prestasi akademik dilakukan dengan menggunakan uji analisis Spearman. Nilai IP setiap mahasiswa akan dihubungkan dengan rata-rata jam/hari mahasiswa tersebut mengakses media sosial. Pemilihan uji korelasi Spearman didasarkan pada data yang dianalisis memiliki distirbusi data yang tidak normal. Berdasarkan hasil uji korelasi Spearman, maka didapatkan bahwa terdapat hubungan yang signifikan antara lama penggunaan media sosial dengan IP belajar mahasiswa. Besar korelasi dari hasil uji tersebut juga memperlihatkan hubungan yang tergolong cukup.

Hasil analisis data untuk menilai hubungan lama penggunaan media sosial sebagai sarana hiburan dengan IP juga menggunakan uji korelasi Spearman. Analisis uji korelasi Spearman memperlihakan bahwa terdapat hubungan yang signifikan antara lama penggunaan media sosial sebagai sarana hiburan dengan IP mahasiswa. Namun, dalam hal ini memiliki koefisien korelasi yang bersifat negatif. Hal ini berarti semakin lama mahasiswa menggunakan media sosial sebagai sarana hiburan, maka semakin rendah IP yang diperolehnya. Besar hubungan pada lama penggunaan media sosial sebagai sarana hiburan dengan IP memiliki nilai yang sama dengan lama pengguaan media sosial sebagai sarana belajar dengan IP, yaitu sama-sama memiliki besar korelasi yang tergolong cukup.

Tabel 6. Hubungan Lama Penggunaan Media Sosial Sebagai Sarana Hiburan dengan Indeks Prestasi

\begin{tabular}{lccc} 
& \multicolumn{3}{c}{ Indeks Prestasi } \\
& $\mathbf{n}$ & $\mathbf{r}$ & $\mathbf{p}$ \\
\hline $\begin{array}{l}\text { Lama Pengunaan } \\
\text { Media Sosial }\end{array}$ & 126 & $-0,568$ & 0,0001 \\
\hline
\end{tabular}

Hasil yang diperoleh dari penelitian ini memperlihatkan bahwa media sosial paling sering digunakan sebagai sarana hiburan. Hal ini sesuai dengan tujuan dari terbentuknya media sosial. Media sosial adalah media berbasis internet yang digunakan untuk dapat melalukan komunikasi kepada kelompok luas. Melalui media sosial seseorang dapat membagi aktifitas yang dilakukannya secara per-orangan ataupun kepada kelompok dan begitupula sebaliknya. Dikarenakan kegunaannya tersebut, maka sudah selayaknya penggunaan media sosial memang tepat digunakan sebagai sarana hiburan.

Selain penggunaan media sosial sebagai sarana hiburan, media sosial juga dapat dimanfaatkan sebagai sarana belajar. Penggunaan media sosial sebagai sarana belajar dapat dilakukan dengan menggunakan video ataupun tulisan yang berasal dari media sosial sebagai sumber belajar. ${ }^{9}$ Perkembangan sekarang ini memungkinkan bagi mahasiswa untuk mencari topik-topik terkait kesehatan di berbagai media sosial yang ada. Bila dahulu media sosial hanya digunakan sebagai media untuk bersosialisasi saja, maka sekarang ini banyak media sosial yang memberikan informasi-informasi terkait dengan penjelasan materi-materi tertentu. Informasi-informasi tersebut dapat membantu mahasiswa dalam mempelajari dan memahami tentang suatu topik tertentu.

Pemanfaatan media sosial sebagai sarana dalam memahami konten belajar sering dilakukan oleh mahasiswa-mahasiswa yang memiliki keinginan kuat dalam berinteraksi secara sosial. ${ }^{9,10}$ Mahasiswa 
yang memiliki pertemanan di kampus akan cenderung menggunakan media sosial untuk tetap berkomunikasi diantara mereka. ${ }^{11}$ Komunikasi yang dilakukan oleh mahasiswa tersebut tidak hanya tentang interaksi sosial tetapi juga terhadap tugastugas atau topik-topik kuliah yang sedang dipelajari. Namun, ada juga mahasiswa yang tidak tertarik dalam menggunakan media sosial, baik dikarenakan alasan mengganggu privasi dirinya ataupun karena tidak memiliki ketertarikan menggunakan media sosial. Berdasarkan hal tersebut, dapat disimpulkan keinginan untuk menggunakan media sosial disetiap orang akan berbeda-beda tujuannya. Namun, pemanfaatan media sosial sebagai sarana dalam belajar, bukanlah suatu hal yang tidak mungkin untuk dilakukan.

Penggunaan media sosial sebagai sarana belajar dapat efektif dilakukan bila pembelajaran ditujukan untuk: 1) memberi kesempatan kepada mahasiswa untuk memperluas pengetahuan dengan berinteraksi dengan pakar lain diluar dosen pengajar; 2) memberi kesempatan kepada mahasiswa untuk belajar secara kolaboratif; dan 3) memberikan tugas yang cocok dengan penggunaan media sosial. ${ }^{12}$ Berdasarkan penjelasan tersebut, maka institusi ataupun dosen pengajar harus merancang proses pembelajaran agar sesuai atau memenuhi ke-tiga kriteria di atas. Proses belajar dengan mendekatkan jarak antara pembelajar dan dosen berguna dalam meningkatkan pemahaman pembelajar tentang topik yang dipelajari. Media sosial tersebut biasanya akan diintegrasikan dengan kurikulum pembelajaran suatu institusi.

Di atas telah dijelaskan bahwa penggunaan media sosial dalam belajar dapat dilakukan dengan menekankan pada komunikasi antar pembelajar dan komunikasi dengan dosen. Namun, penggunaan media sosial dapat juga dimanfaatkan sebagai sumber belajar yang dapat meningkatkan pemahaman serta memperkaya pengetahuan mereka. ${ }^{13}$ Informasi pengetahuan yang didapat oleh mahasiswa melalui media sosial umumnya diperoleh dari website youtube. Video yang diperoleh dari website youtube dapat digunakan sebagai materi pembelajaran di bidang kedokteran, seperti mempelajari tentang anatomi. ${ }^{14,15}$ Mempelajari anatomi akan sulit bila tidak melihat objek yang dipelajari secara nyata. Pemanfaatan video youtube dalam memahami bagian-bagian anatomi secara nyata dapat membantu mahasiswa dalam belajar.

Website yang termasuk dalam kelompok media sosial sangatlah banyak. Tetapi tidak semua website tersebut mendukung dalam proses pembelajaran. Hanya ada beberapa website yang mungkin dapat digunakan sebagai sarana dalam belajar, yaitu: youtube, wikipedia dan blogger. Sedang media sosial lainnya lebih dimanfaatkan untuk komunikasi sosial. ${ }^{11}$ Dari ketiga website media sosial tersebut, website youtube adalah website yang paling lama diakses dalam membantu proses belajar. Hasil serupa diperoleh oleh $\mathrm{Liu}^{11}$ yang menyampaikan bahwa youtube, facebook dan wikipedia adalah tiga jenis media sosial yang paling dikenal oleh mahasiswa. Penjelasan mengapa hal ini terjadi mungkin dikarenakan materi-materi disampaikan melalui media sosial tersebut divisualisasikan secara jelas, sehingga materi-materi yang sulit untuk dipahami dapat lebih mudah untuk dimengerti dengan menggunakan media sosial tersebut.

Website terlama yang digunakan oleh mahasiswa sebagai sarana belajar diurutan kedua adalah Wikipedia. Wikipedia digunakan oleh mahasiswa untuk belajar sebagai pengantar dalam mempelajari materi-materi di bidang kedokteran. Meskipun begitu hal-hal yang telah disampaikan di Wikipedia tidak boleh dijadikan bahan referensi yang terpercaya karena sifat dari tulisan yang dibuat dalam Wikipedia, dimana setiap orang bebas untuk mengganti, menambah, ataupun mengurangi materi yang ada dalam Wikipedia tersebut. ${ }^{11}$ Akibatnya konten yang disampaikan dalam Wikipedia dapat lebih luas dan lebih rinci dibandingkan dengan Blog. Mungkin karena alasan inilah lama akses Wikipedia diurutan ke dua setelah youtube.

Selain penggunaan media sosial sebagai sarana belajar, mahasiswa juga menggunakan media sosial sebagai sarana hiburan. Penggunaan media sosial sebagai sarana hiburan oleh mahasiswa yang terlama diakses adalah instagram, yaitu lebih dari 5 jam perhari. Instagram menjadi yang terlama dibuka oleh mahasiswa mungkin dikarenakan konsep media sosial yang menggunakan foto dan video sebagai media dalam bersosialisasi, hal ini berbeda dengan 
media sosial lain yang hanya menggunakan tulisan atau video saja.

Youtube dan facebook menjadi media sosial terlama diakses kedua dan ketiga setelah instagram yang digunakan sebagai sarana hiburan. Bila melihat dari hasil penelitian ini, maka dapat dilihat bahwa media sosial yang terbanyak digunakan sebagai sarana hiburan adalah media sosial berbasis video dan foto, yaitu instagram, youtube dan facebook. Sedangkan media sosial yang berbasis teks saja atau foto saja sedikit diakses oleh mahasiswa. Hal ini mungkin disebabkan informasi yang diberikan dalam bentuk video dan foto memiliki tampilan yang lebih menarik dibandingkan hanya berupa tulisan saja.

Beberapa penelitian mendapatkan bahwa lama penggunaan media sosial dapat mempengaruhi prestasi akademik mahasiswa. ${ }^{16,17}$ Mahasiswa yang mengakses media sosial dalam jangka waktu yang lama akan berdampak pada prestasi akademisnya yang juga akan menurun. Hal ini biasanya terjadi disebabkan penggunaan media sosial sebagai sarana hiburan saja. Mahasiswa yang memiliki ketergantungan (adiksi) pada media sosial pada akhirnya akan mempengaruhi prestasi akademis mereka. Namun penelitian lainnya memperlihatkan tidak adanya hubungan lama penggunaan media sosial terhadap prestasi akademik. ${ }^{18}$ Perbedaan hasil tersebut mungkin disebabkan tidak ada pemisahan antara penggunaan media sosial sebagai sarana belajar atau penggunaan media sebagai sarana hiburan.

Penggunaan media sosial sebagai sarana hiburan masih lebih dominan digunakan dibandingkan dengan menggunakan media sosial sebagai sarana belajar. Penggunaan media sosial sebagai sarana belajar terbanyak hanya digunakan selama kurang dari 1 jam per-harinya, sedangkan penggunaan media sosial sebagai sarana hiburan terbanyak selama 1-2 jam per-harinya. Berdasarkan hasil tersebut dapat disimpulkan bahwa mahasiswa masih belum menggunakan media sosial secara optimal dalam membantu mereka untuk proses belajar. Padahal penggunaan media sosial yang ditujukan membantu mahasiswa dalam proses belajar dapat meningkatkan prestasi akademik mahasiswa.
Hubungan penggunaan media sosial terhadap prestasi akademik mahasiswa pada penelitian ini dapat berkorelasi positif (penggunaan media sosial sebagai sarana belajar) dan dapat berkorelasi negatif (penggunaan media sosial sebagai sarana hiburan). Mahasiswa yang lebih lama mengakses media sosial sebagai sarana belajar memiliki korelasi yang kuat terhadap prestasi akademik. Sebaliknya, penggunaan media sosial sebagai sarana hiburan memiliki korelasi yang kuat untuk dapat menurunkan prestasi akademik mahasiswa. Hasil penelitian ini juga memberi masukan kepada setiap institusi pendidikan, khususnya institusi pendidikan dokter untuk dapat memperkenalkan pemanfaatan media sosial dalam membantu mahasiswa dalam belajar. Pemanfaatan media sosial juga dapat membantu meningkatkan kemampuan mahasiswa dalam belajar secara mandiri.

Upaya dalam memanfaatkan media sosial sebagai sarana belajar dapat dilakukan dengan memperkenalkan berbagai jenis media sosial yang dapat digunakan dalam proses belajar dan mengajarkan teknik penggunaan media sosial tersebut. ${ }^{19}$ Seperti yang telah disampaikan di atas bahwa belajar di pendidikan dokter merupakan suatu hal yang kompleks, maka dari itu diperlukan suatu media belajar yang membantu memudahkan mahasiswa untuk memahami konten materi yang diajarkan. Teori yang disampaikan oleh Edgar Dale menyatakan bahwa penggunaan video sebagai media belajar akan meningkatkan kemampuan penyerapan informasi lebih baik dibandingkan dengan hanya menggunakan teks atau tulisan saja. ${ }^{20}$ Penggunaan video akan lebih baik dalam membentuk pengalaman belajar dibandingkan dengan penggunaan media tulis atau gambar saja. Kualitas pengalaman belajar yang lebih baik otomatis akan meningkatkan penyerapan informasi yang disampaikan. Berdasarkan teori tersebut, maka penggunaan media sosial yang berbasis pada video seperti youtube dapat meningkatkan penyerapan informasi lebih baik dalam proses belajar.

Informasi yang terdapat di internet sangatlah banyak, maka diperlukan suatu keterampilan tertentu untuk dapat memilih dan memilah 
informasi tersebut. Pemanfaatan media sosial sebagai sarana belajar juga memerlukan keterampilan memilih dan memilah informasi agar dapat menemukan informasi yang sesuai dan akurat yang dapat membantu mahasiswa memahami konten pembelajaran tertentu. Dikarenakan pentingnya penguasaan keterampilan ini, maka mahasiswa harus diajarkan tentang keterampilan ini sejak awal belajar di institusi pendidikan dokter.

Media sosial memang awalnya ditujukan untuk memudahkan seseorang dalam berkomunikasi dengan orang lain. Namun, seiring perkembangan zaman maka media sosial juga mengalami perubahan. Awal dari pembentukannya, media sosial hanya berupa tulisan dan gambar yang kemudian berkembang menjadi bentuk video yang lebih menarik dan nyata. Perkembangan teknologi komunikasi dan perekaman juga menjadi alasan mengapa media sosial berbasis video lebih digemari. Konten-konten yang disampaikan dalam media sosial juga mengalami perubahan, dimana awalnya hanya untuk berkomunikasi dengan teman atau kelompoknya menjadi tempat berbagi informasiinformasi tertentu. Informasi yang dibagi dapat berupa informasi pribadi maupun informasi tentang pengetahuan keilmuan tertentu. Setiap orang dapat dengan mudah berbagi informasi-informasi tertentu melalui media sosial. Perkembangan fungsi dan peran dari media sosial ini bukan tidak mungkin dimanfaatkan sebagai sarana belajar mahasiswa.

Pada masa sekarang ini, setiap orang telah memiliki gawai yang dapat digunakan untuk mengakses media sosial dengan mudah. Kemudahan dalam mengakses media sosial ini dapat membantu pembelajar khususnya mahasiswa untuk dapat mengakses informasi-informasi tertentu yang membantu dirinya dalam memahami topik yang dipelajarinya. Media sosial juga dapat membantu mahasiswa dalam berkomunikasi dengan dosennya dalam proses pembelajaran. ${ }^{21}$ Atas dasar perkembangan, kemudahan dan hasil yang didapat berupa peningkatan prestasi akademik mahasiswa dari penggunaan media sosial sebagai sarana belajar, maka dapat dipertimbangkan penggunaan media sosial sebagai suplemen dalam mempelajari konten ilmu kedokteran. Namun, sebagai catatan penggunaan media sosial yang tidak tepat juga dapat berefek buruk bagi prestasi akademik mahasiswa.

Hasil yang didapat dalam penelitian ini perlu dilakukan pengkajian lebih lanjut, karena penelitian ini hanya berlaku pada kelompok mahasiswa FK UISU saja. Peneliti juga menyadari faktor kepribadian mahasiswa juga dapat mempengaruhi hasil penelitian ini. Mahasiswa yang sudah terbiasa atau senang menggunakan media sosial dapat lebih gampang untuk belajar, sedangkan mahasiswa yang memiliki kepribadian interpersonal yang rendah akan sulit menggunakan media sosial sebagai sarana belajar. Agar efek pasti penggunaan media sosial sebagai sarana belajar dapat tergambar lebih jelas, maka diperlukan penelitian di lokasi lain di Indonesia. Disain penelitian yang digunakan untuk menganalisis efek penggunaan media sosial sebagai sarana belajar perlu menggunakan disain yang lebih kuat lagi, misal menggunakan disain penelitian eksperimen sehingga variabel-variabel perancu yang mungkin mempengaruhi hasil dari penelitian ini dapat dikontrol.

\section{KESIMPULAN}

Media sosial adalah suatu alat berbasis internet yang digunakan untuk berkomunikasi dengan orang banyak. Sesuai dengan perkembangannya, media sosial tidak hanya dapat digunakan sebagai saran hiburan tetapi juga dapat digunakan sebagai sarana belajar. Hasil penelitian ini memperlihatkan bahwa lama penggunaan media sosial memiliki hubungan yang kuat dengan prestasi akademik mahasiwa. Mahasiswa yang sering menggunakan media sosial sebagai sarana belajar akan memiliki prestasi akademik yang baik, sedangkan mahasiswa yang menggunakan media sosial sebagai sarana hiburan akan berdampak menurunkan prestasi akademiknya. Penggunaan media sosial memiliki dampak yang positif dan negatif tergantung pada tujuan penggunaan media sosial tersebut.

\section{DAFTAR PUSTAKA}

1. Daruyani S, Wilandari Y, Yasin H. Faktor-faktor yang mempengaruhi indeks prestasi mahasiswa FSM universitas diponegoro semester pertama 
dengan metode logistik biner. Prosiding Seminar Nasional Statistika Universitas Diponegoro. 2013: 185-94

2. Daely K, Sinulingga U, Manurung A. Analisis statistik faktor-faktor yang mempengaruhi indeks prestasi mahasiswa. Jurnal Saintia Matematika. 2013;1(5):483-94.

3. Oktavianingtyas, E. Studi tentang faktor-faktor yang mempengaruhi prestasi belajar mahasiswa program studi pendidikan matematika FKIP Universitas Jember. Jurnal Ilmu Pendidikan. 2013;4(2):13-26.

4. Setyani NI. Penggunaan media sosial sebagai sarana komunikasi bagi komunitas. Jurnal Komunikasi. 2013;2(3):1-15.

5. Nasrullah R. Media Sosial Perspektif Komunikasi, Budaya, dan Sosioteknologi. Jakarta: Simbiosa Rekatama Media; 2016.

6. Jumiatmoko. Whatsapp messenger dalam tinjauan manfaat dan adab. Wahana Akademika. 2016;3(1):52-66.

7. Setyaningrum DG, Sultoni, Huda M. Hubungan penggunaan media jejaring sosial dengan prestasi akademik mahasiswa di Fakultas Ilmu Pendidikan Universitas Negeri Malang [Skripsi]. Malang (Indonesia): Universitas Negeri Malang; 2016.

8. Pramudawardani A. Pengaruh intensitas penggunaan jejaring sosial facebook dan twitter terhadap prestasi akademik mahasiswa pendidikan IPS. Jurnal Pendidikan IPS. 2016;2(2):2-18.

9. Taylor R, King F, Nelson G. Students learning through social media. Journal of Sociological Research. 2012;3(2):29-35.

10. Delello JA, Mcwhorter RR, Camp KM. Using media sosial as a tool for learning: a multi-disciplinary study. International Journal on e-learning. 2015; $14(2): 163-80$
11. Liu Y. Social media tools as a learning resource. Journal of Educational Technology Development and Exchange. 2010;3(1):101-14.

12. Henderson M, Snyder I, Beale D. Social media for collaborative learning: a review of school literature. Australian Educational Computing. 2013;28(2).

13. Yeo MML. Social media and social networking applications for teaching and learning. European Journal of Science and Mathematics Education. 2014;2(1):53-62.

14. Jaffar AA. Youtube: an emerging tool in anatomy education. Anat Sci Educ. 2012;5:158-64.

15. Reveron RR. The use of youtube in learning human anatomy by venezuelan medical students. MOJ Anat Physiol. 2016;2(7):200-3.

16. Peter $\mathrm{O}$. Social media and academic performance of students. Conference Paper at University of Lagos. 2015.

17. Nsizwana SC, Ige KD, Tshabalala NG. Social media use and academic performance of undergraduate students in students in south african higher institutions: the case of the University of Zululands. Journal of Social Science. 2017;5(1-3):141-52.

18. Alwagait E, Shahzad B, Alim S. Impact of social media usage on students academic performance in Saudi Arabia. Computer in Human Behaviour Journal. 2015;51:1092-7.

19. Thalluri J, Penman J. Social media for learning and teaching undergraduate scinces: good practice guidelines for intervention. 2015;13(6):455-65.

20. Dale E. Audio-Visual Methods in Teaching. New York: Dryden Press; 1946.

21. Gurcan HI. Contribution of social media to the student's academic performance. International Journal of Information and Education Technology. 2015;5(12):965-68 